\title{
REPRODUCTIVE BIOLOGY OF OVIGEROUS FEMALE Emerita emeritus (Crustacea, Decapoda) IN BENGKULU COASTAL WATERS, INDONESIA: EGG PRODUCTION AND REPRODUCTIVE OUTPUT
}

\author{
Quratul Edritanti ${ }^{1}$, Achmad Farajallah $^{2}$, Yusli Wardiatno ${ }^{* 3}$
}

${ }^{1}$ Master Program in Animal Biological Science, Department of Biology, Faculty of Mathematics and Natural Science, Bogor Agricultural University, Kampus IPB Darmaga, Bogor 16680, Indonesia

${ }^{2}$ Department of Biology, Faculty of Mathematics and Natural Science, Bogor Agricultural University, Kampus IPB Darmaga, Bogor 16680, Indonesia

${ }^{3}$ Department of Aquatic Resources Management, Faculty of Fisheries and Marine Science, Bogor Agricultural University, Kampus IPB Darmaga, Bogor 16680, Indonesia

*Corresponding Author, Email: yusli@ipb.ac.id

\section{ARTICLE INFO}

Received: 5 May 2016

Received in revised form: 19 June 2016

Accepted: 27 June 2016

Available online: 27 June 2016

\begin{abstract}
Emerita emeritus is an abundant species in Bengkulu coastal waters, but the knowledge of its reproductive biology is poor. The present study was conducted to elucidate the reproductive aspects of ovigerous female $E$. emeritus, including fecundity, egg volume and reproductive output. This study was conducted between January 2015 and January 2016 in Bengkulu coastal waters, Indonesia. Samples were collected manually using shovels and hands. The results showed that ovigerous females occurred every month. Fecundity increased significantly in ovigerous females proportional to the size. No correlation was shown between sea surface temperature and egg production. Fecundity and reproductive output decreased throughout the embryonic development.
\end{abstract}

Keywords:

Egg production

Embryonic development

Hippoidea

Intertidal fishery

Mole crab
How to Cite

Edritanti, Q., Farajallah, A., Wardiatno, Y. (2016): Reproductive biology of ovigerous female Emerita emeritus (Crustacea, Decapoda) in Bengkulu coastal waters, Indonesia: egg production and reproductive output. Croatian Journal of Fisheries, 74, 103-109. DOI: 10.1515/cjf-2016-0018.

\section{INTRODUCTION}

Indonesia is rich in terms of crustacean biodiversity, including hippoid crabs. Current researches show that there are at least seven species of hippoid crabs in Indonesia, i. e. Emerita emeritus, Hippa adactyla, $H$. admirabilis, $H$. marmorata, $H$. ovalis, $H$. celaeno and Albunea symmista (Mashar et al., 2014; Ardika et al., 2015; Mashar et al., 2015; Wardiatno et al., 2015a,b). In some parts of Indonesian coastal waters (e.g. Bengkulu, Sumatra Island and Cilacap, southern part of Java Island), hippoid crabs are the target of intertidal fishery.

Generally crabs live by burrowing themselves under the substrate in the swash zone of intertidal sandy areas (Sarong and Wardiatno, 2013; Wardiatno et al., 2014). In their habitat, hippoid crabs have ecological values, such as contributing a significant secondary benthic production (Subramoniam and Gunamalai, 2003) and serving the trophic level (Lercari and Defeo, 1999; Hubbard and Dugan, 2003; Hidalgo et al., 2010). They are also useful for humans as nutritious food 
source (Santoso et al., 2015) or as an indicator species of polycyclic aromatic hydrocarbons pollution (Dugan et al., 2005). The distribution of the seven species of Indonesian hippoid crabs is revealed by Wardiatno et al. (2015b). Emerita emeritus occurs mainly in the Indian Ocean, both in the west coast of Sumatra and in the south coast of Java. It lives sympatrically with the other two hippoid crabs, i.e. Hippa adactyla and Albunea symmista (Mashar et al., 2014; Wardiatno et al., 2015b). Research on biological aspects of Indonesian hippoid crabs has been published, i.e. their occurrence and distribution in Indonesian coastal waters (Ardika et al., 2015; Mashar et al., 2015; Wardiatno et al., 2015a,b), habitat characteristics (Sarong and Wardiatno, 2013; Wardiatno et al., 2014), allometric growth (Mashar and Wardiatno 2013a,b; Muzammil et al., 2015), monthly abundance fluctuations (Mashar et al., 2014) and biochemical contents (Santoso et al., 2015). However, none of the studies were related to the reproductive biology.

The present study was conducted to elucidate the reproductive aspects of $E$. emeritus, including fecundity, egg characteristics and reproductive output. In addition, comparison with other crustaceans is discussed.

\section{MATERIALS AND METHODS}

\section{Study area}

Individuals of $E$. emeritus were collected in the sandy intertidal zone along Bengkulu coastal line, Sumatra Island (Fig. 1). Samplings were conducted once a month between January 2015 and January 2016. Collections were made by digging the sand using a shovel, and the emerged ovigerous crabs were caught by hand. The collected crabs were put into individual plastic bags and preserved by $70 \%$ alcohol for laboratory work. Surface water temperature was measured as temperature was proved to correlate with egg production in previous researches on hippoid crabs (see Defeo et al., 2001; Defeo and Cardoso, 2002).

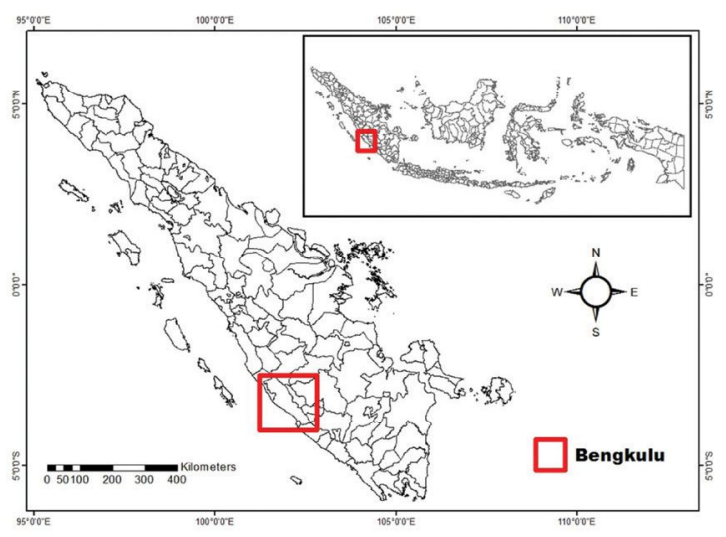

Fig 1. Map of Sumatra Island, Indonesia. Sampling site is indicated by the red rectangular

\section{Specimen treatments}

In laboratory, prior to egg detachment from pleopods, total length (TL: from anterior carapace margin to posterior region of telson; Fig. 2 a) and carapace length (CL: from anterior to posterior carapace margin; Fig. 2 b) was measured with digital calliper to the nearest $0.05 \mathrm{~mm}$.
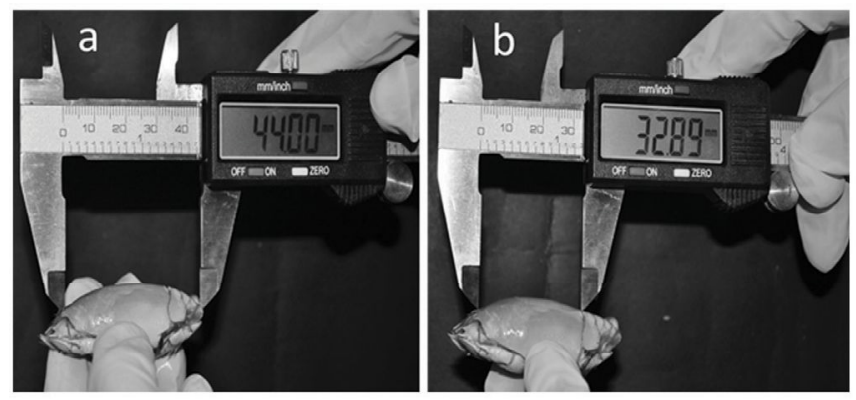

Fig 2. Total length (a) and carapace length (b) measurements of Emerita emeritus

Egg related work processes and treatments followed Hernáez et al. (2008). The total egg mass was detached from pleopods of ovigerous crabs and three subsamples of 100 eggs each were separated and then dried for $48 \mathrm{~h}$ at $65^{\circ} \mathrm{C}$ together with the remaining egg mass. Afterward, the weight of each subsample and the remaining egg mass were measured by an analytical balance to the nearest $0.1 \mathrm{mg}$. Egg weight and total egg number were calculated according to the following equations:

$E=S / 100$

$\mathrm{NE}=\mathrm{OM} / \mathrm{E}$

with $\mathrm{E}=$ egg weight, $\mathrm{S}=$ average weight of subsample, $\mathrm{NE}=$ total egg number; $\mathrm{OM}=$ weight of total egg mass.

In this study, egg development was classified into three stages (Stage I-III) following Wehrtmann (1990). For calculating egg volume, 20 eggs from the egg mass Stage I were taken and the width and length of each egg were measured under a microscope equipped with a calibrated ocular micrometer. These data were used to calculate egg volume (EV) according to the formula proposed by Turner and Lawrence (1979) for oblate spheroids:

$\mathrm{EV}=1 / 6\left(\mathrm{a} \times \mathrm{b}^{2} \times \mathrm{m}\right)$

where "a" represents length, and "b" width. The reproductive output (RO) was estimated using the formula developed by Clarke et al. (1991), i.e. dry weight of the entire egg mass is divided by dry weight of the female without eggs.

\section{Data analyses}

Allometric equation $\left(Y=a X^{b}\right)$ was used to show the relation between fecundity and female size. The equation has been applied in analogous studies on other decapods (e.g. Hines, 1991; Corey and Reid, 1991). With this equation, the relation is isometric if "b" value is about 3 (Somers, 1991). 
In their study, Hernáez and Wehrtmann (2007) considered a negative allometric relation if "b" value is lower than 2.90 , and positive allometric relation if " $b$ " value is higher than 3.10. Spearman rank correlation was used to reveal the relationships between sea surface temperature and egg production (stage I only) (Fowler and Cohen, 1992).

\section{RESULTS}

A number of 287 individuals of ovigerous female $E$. emeritus were collected during the study. The carapace length ranged from 22.00 to $41.99 \mathrm{~mm}$. The most dominant size of the ovigerous female was between CL 26.00 and $29.99 \mathrm{~mm}$. The fecundity range was between 419 and 4572 eggs (average: $1491 \pm 46$ ). Fecundity increased significantly in ovigerous females proportional to the size (Table 1). The results showed the number of eggs relation to body size and weight is positive allometric. Based on ANOVA test, the number of eggs of $E$. emeritus was significantly different between stage I and II, and I and III ( $P<0.1)$, but not between stage II and III ( $P>0.05)$ (Fig. 3). Sea surface temperature varied seasonally (Fig. 4). The warmest temperature was recorded in July. Spearman rank correlation showed a nonsignificant correlation between egg number (Stage I only) and sea surface temperature $(\mathrm{P}>0.05)$.

Table 1. The correlation between egg number (only Stage I) and crab size in E. emeritus population collected from Bengkulu waters, Indonesia

\begin{tabular}{llll}
\hline Equation & $\mathrm{R}$ & $\mathrm{R}^{2}$ & $\mathrm{~N}$ \\
\hline Fecundity versus size & & & \\
1. $\log \mathrm{NE}=3.748 \log \mathrm{CL}-2.525$ & 0.98 & 0.96 & 118 \\
2. $\log \mathrm{NE}=3.5083 \log \mathrm{TL}-2.7347$ & 0.87 & 0.76 & 118 \\
\hline \hline
\end{tabular}

Note: $\mathrm{R}=$ correlation coefficient, $\mathrm{R}^{2}=$ determination coefficient, $\mathrm{N}=$ number of females analyzed, $\mathrm{CL}=$ carapace length, $\mathrm{NE}=$ number of eggs, TL= total length.

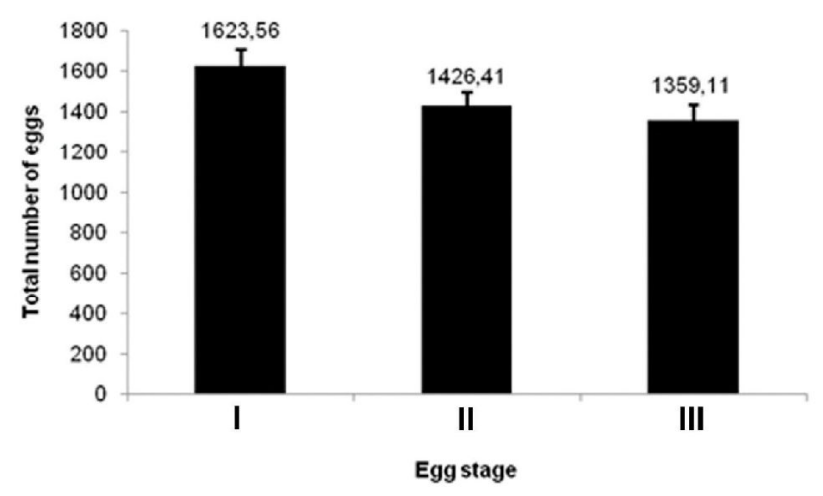

Fig 2. Number of eggs of ovigerous female Emerita emeritus from Bengkulu coastal waters, Indonesia

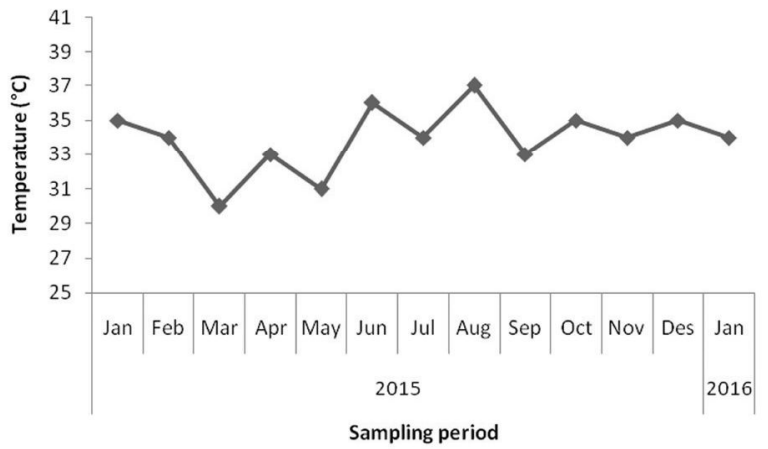

Fig 4. Sea surface temperature variation of Bengkulu coastal waters, Indonesia during research period

This study revealed that ovigerous female occurred every month (Fig. 5), however, the figure illustrates two peaks of Stage I egg, i.e. in February and June. Following the occurrence of Stage III egg, it showed a time lag about 1 - 2 months between February and April, and between April and June to develop from Stage I to Stage III.

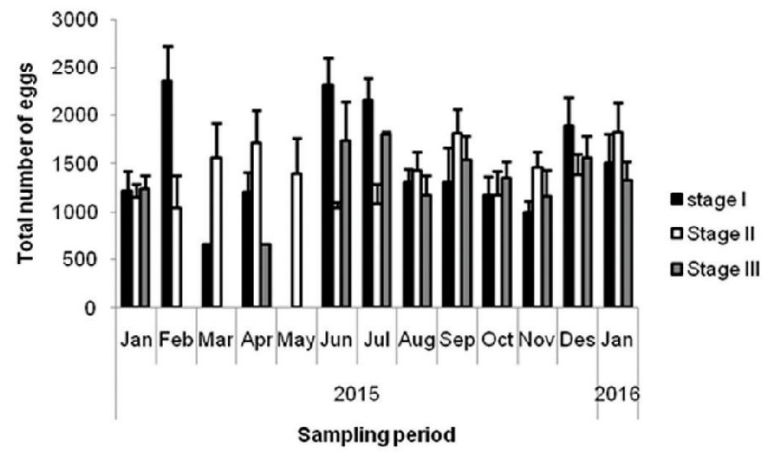

Fig 5. Number of eggs carried by the ovigerous female Emerita emeritus of Bengkulu coastal waters, Indonesia

During embryogenesis, volume of eggs increased in each stage, i.e. stage I was $0.040 \pm 0.0008 \mathrm{~mm}^{3}$, stage II was $0.044 \pm 0.001 \mathrm{~mm}^{3}$, and stage III was $0.054 \pm 0.001 \mathrm{~mm}^{3}$. The increasing of egg volume was linear with the diameter. Females inverted on average 5.13, 4.63 and $3.85 \%$ of their dry weight into egg production for Stage I, Stage II and Stage III, respectively (Fig. 6).

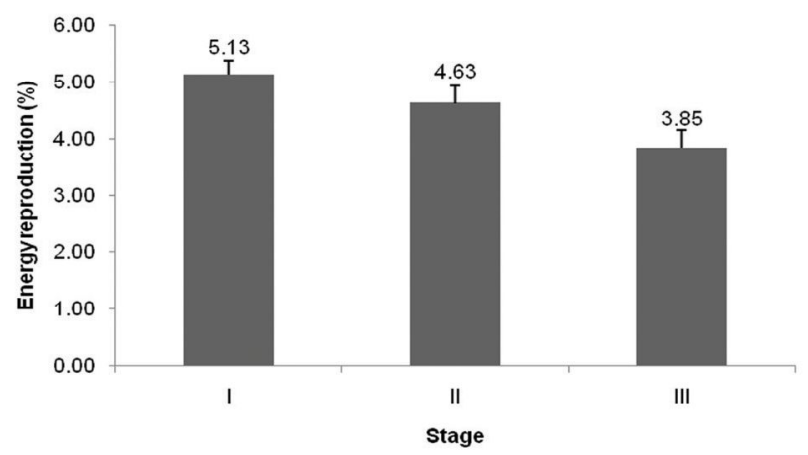

Fig 6. Mean value and standard deviation of reproductive output with different embryonic development stage of ovigerous female Emerita emeritus collected from Bengkulu coastal waters, Indonesia 


\section{DISCUSSION}

The crabs of family Hippidae are widely distributed all over the world (Efford, 1976), and in Indonesia at least seven species have been reported (Wardiatno et al., 2015b). It has been a long time since research on egg production of hippid crabs has received much attention (e.g. Efford, 1969; Subramoniam, 1977, 1979; Diaz, 1980; Wenner et al., 1987; Defeo et al., 2001; Defeo and Cardoso, 2002). As shown in Table 1 and Fig. 2, the number of eggs increased with size. It is not an uncommon phenomenon in crustaceans that female generate more eggs as their size expands (e.g. Van Dolah and Bird, 1980; Hartnoll, 1985; Wenner et al., 1987; Defeo et al., 2001; Defeo and Cardoso, 2002; Sáez-Royuela et al., 2006; Cobo and Okamari, 2008; Hernáez et al., 2008; Verísimo et al., 2011). Size related egg phenomenon in crustaceans has been an attractive theme in several species over the last four decades, such as isopods (Paris and Pitelka, 1962; Lawlor, 1976a,b), mysids (Mauchline, 1973), prawns (Wickens and Beard, 1974), amphipods (Von Dolah and Bird, 1980), hermit crabs (Bertness, 1981), krill (Denys and McWhinnie, 1982), copepods (Carter et al., 1983) and lobsters (Ennis, 1981). The same trend, producing larger numbers of eggs as they grow bigger, was actually also revealed by other animals with indeterminate growth, such as fish (e.g. Love and Westphal, 1981; Baltz and Knight, 1983).

Number of eggs produced by crustaceans could give important information on the rate of recruitment in the population. Information about fecundity grants a better consideration of the reproductive strategies, dynamics and evolution of the population (García-Montes et al., 1987). By seeing the two peaks of stage I egg production in Fig. 3, it seemed that the population had bimodal egg production, which is probably followed by bimodality of the recruitment. However, this pattern must be proved with the life history study and/or the success in planktonic larval settlement study. Bimodality of egg production was also exhibited by other crustaceans, such as callianassid shrimp (Tamaki et al., 1997; Wardiatno, 2002). Fig. 3 also shows variability in number of pleopodal eggs. The variability could be influenced by several factors, such as population, year of breeding, female size, embryonic development stage and food availability as well as environmental conditions (Cox and Dudley, 1968; Wenner, 1977; Fusaro, 1978; Dugan et al., 1994; Defeo et al., 2001; Defeo and Cardoso, 2002; Sáez-Royuela et al., 2006). Some studies have shown that seasonal water temperature had a correlation with the variation of egg production in hippoid crabs (Defeo et al., 2001; Defeo and Cardoso, 2002), but it is not the case in this study.
Comparing egg production of other hippoid crab species, the egg production of $E$. emeritus is lower than that of $E$. brasiliensis. Mean value of the egg production of $E$. brasiliensis was 3704 in Urca-Brazil, 6991 in ArachaniaUruguay and 8287-9099 in Barra del Chuy-Uruguay (Defeo et al., 2001; Defeo and Cardoso, 2002). Yet, the mean value of egg production of $E$. emeritus is under the range of $E$. analoga (1386-11937) of northern Chile (Contreras et al., 2000). Defeo and Cardoso (2002) suggested a clear morphodynamic effect to the egg production of $E$. brasiliensis by comparing its egg production in a reflective beach and in a dissipative one in Uruguay. They concluded that E. brasiliensis had higher egg production in a dissipative beach.

As stated above, the embryonic development stage is one factor that affected the number of eggs in crustacean pleopods (Sáez-Royuela et al., 2006). The same result is shown in this study (Fig. 2). The egg production decreases throughout the embryonic development (Celada et al., 1988; Taugbøl and Skurdal, 1990; Reynolds et al., 1992). As the egg develops, the volume of egg increases, while the space in the abdomen of the female does not get any bigger. Therefore the number of eggs should be reduced. In addition, some other factors may be behind the decrease or the loss of eggs during the egg development. Generally brachyuran crabs carry their eggs attached to the pleopodal setae, making the mass egg partially exposed. As a consequence, the surface layers of eggs would probably be susceptible to impairment from inestimable sources, i.e. strike of pathogens and/ or parasites (Shields, 1991), dynamic subtraction at some stage when the crab grooms or when the crab is in tense situations (Norman and Jones, 1993) and long phases of development that augment egg loss by interacting with the substrate (Talbot, 1991).

Similar to the pattern of the egg number, the reproductive output (RO) decreased linearly with the embryonic development stage (see Fig. 4). By seeing the average values, the RO is still under the range of some brachyuran crabs [3-22\%] (Hines, 1991), but it is lower than that of callianassid shrimps [14.9-19.6\%] (Thessalou and Kiortsis, 1997; Hernáez et al., 2008) and that of deepsea crabs [16-22\%] (Hines, 1988). However, compared to atyid shrimp Atya scabra with RO 3.6\% (Herrera-Correal et al., 2013), the RO of E. emeritus is higher.

\section{ACKNOWLEDGEMENTS}

We thank Ms. Yuyun Qonita for her help in giving tutorial to the first author in data analysis. Mr. Agus Alim Hakim prepared pictures in TIFF form. This work is part of the first author master thesis. Two anonymous reviewers are thanked for their constructive comments. 


\section{Sažetak}

\section{REPRODUKTIVNA BIOLOGIJA OVIGERNIH ŽENKI Emerita emeritus (Crustacea, Decapoda) U OBALNIM VODAMA BENGKULUA, INDONEZIJA: PROIZVODNJA JAJA I REPRODUKTIVNI ISHOD}

Emerita emeritus je brojna vrsta u priobalnim vodama Bengkulua, ali je poznavanje njezine reproduktivne biologije slabo. Ova studija je provedena kako bi se razjasnili reproduktivni aspekti ženki $E$. emeritus, uključujući plodnost, volumen jaja te reproduktivni učinak. Istraživanje je provedeno u razdoblju od siječnja 2015. do siječnja 2016. u priobalnim vodama Bengkulua, Indonezija. Uzorci su prikupljeni ručno uz pomoć lopate i rukama. Rezultati indiciraju konstantnu pojavu ženskih matica svakog pojedinog mjeseca. Plodnost se značajno povećavala u proporciji sa veličinom. Nije uočena korelacija između temperature površine mora i proizvodnje jaja. Plodnost i reproduktivni ishod se smanjio tijekom embrionalnog razvoja.

Ključne riječi: proizvodnja jaja, embrionalni razvoj, hippoidea, međuplimno ribarstvo, Mole rakovi

\section{REFERENCES}

Ardika, P. U., Farajallah, A., Wardiatno, Y. (2015): First record of Hippa adactyla (Fabricius, 1787; Crustacea, Anomura, Hippidae) from Indonesian Waters. Tropical Life Sciences Research, 26, 2, 105-110.

Baltz, D. M., Knight, E. E. (1983): Age, growth, reproductive characteristics and seasonal depth distribution ofthe spotfin surfperch Hyperproson anale. California Fish and Game, 69, 97-104.

Bertness, M. D. (1981): Pattern and plasticity in tropical hermit crab growth and reproduction. American Naturalist, 117, 754-773.

Carter, J. C. H., Sprules, W. O., Dadswell, M. J., Roff, J. C. (1983): Variation in body size of Diaptomus minutus (Copepoda, Calanoida). Canadian Journal of Fisheries and Aquatic Sciences, 40, 1303-1307.

Celada, J. D., Carral, J.M., Gaudioso, V. R., Tem o, C., Fernandez, R. (1988): Effects of thermic manipulation throughout egg development on the reproductive efficiency of the freshwater crayfish (Pacifastacus leniusculus Dana). Aquaculture, 72, 341-348.

Clarke, A., Hopkins, C. C., Nilssen, E. M. (1991): Egg size and reproductive output in the deep water prawn Pandalus borealis Kroyer, 1838. Functional Ecology, 5, 724-730.

Cobo, V. J., Okamori, C. M. (2008): Fecundity of the spider crab Mithraculus forceps (Decapoda, Mithracidae) from the northeastern coast of the state of São Paulo, Brazil.
Iheringia Série Zoologia, 98, 1, 84-87.

Contreras, H., Jaramillo, E., Quijon, P. (2000): Natural history of Emerita analoga (Stimpson) (Anomura, Hippidae) in a sandy beach of northern Chile. Revista Chilena de Historia Natural, 75, 705-715.

Corey, S. Reid, D. M. (1991): Comparative fecundity of decapod crustaceans. The fecundity of thirty three species of nine families of caridean shrimps. Crustaceana, 60, 270-294.

Cox, G. W., Dudley, D. G. (1968): Seasonal pattern of reproduction of the sand crab Emerita analoga in southern California. Ecology, 49, 746-751.

Defeo, O., Cardoso, R.S. (2002): Macroecology of population dynamics and life history traits of the mole crab Emerita brasiliensis in Atlantic sandy beaches of South America. Marine Ecology Progress Series, 239, 169-179.

Defeo, O., Gomez, J., Lercari, D. (2001): Testing the swash exclusion hypothesis in sandy beach populations: the mole crab Emerita brasiliensis in Uruguay. Marine Ecology Progress Series, 212, 159-170.

Denys, C. J., McWhinnie, M. A. (1982): Fecundity and ovarian cycles of the Antarctic krill Euphausia superba (Crustacea, Euphausiacea). Canadian Journal of Zoology, 60, 24142423.

Diaz, H. (1980): The mole crab Emerita talpoida (Say): A case of changing life history pattern. Ecological Monograph, 50, 437-456.

Dugan, J. E., Hubbard, D. M., Wenner, A. M. (1994): Geographic variation in life history of the sand crab, Emerita analoga (Stimpson) on the California cost: relationships to environmental variables. Journal of Experimental Marine Biology and Ecology, 181, 255-2 78.

Dugan, J. E., Ichikawa, G., Stephenson, M., Crane, D.B., McCall, J., Regalado, K. (2005): Monitoring of coastal contaminants using sand crabs. Central Coast Regional Water Quality Control Board. 37pp.

Efford, I.E. (1969): Egg size in the sand crab, Emerita analoga (Decapoda, Hippidae). Crustaceana, 16, 1-26.

Efford, I. E. (1976): Distribution of the sand crabs in the genus Emerita (Decapoda, Hippidae). Crustaceana, 30, 170183.

Ennis, G. P. (1981): Fecundity of the American lobster, Homarus americanus in Newfoundland waters. Fishery Bulletin, 70, 796-800.

Fowler, C., Cohen, L. (1992): Practical statistics for field biology. John Wiley \& Sons, Chichester. 227pp.

Fusaro, C. (1978): Food availability and egg production: a field experiment with Hippa pacifica Dana (Decapoda; Hippidae). Pacific Science, 32, 1, 17-23.

Garcia-Montes, J. F., Garcia, A., Soto, L. A. (1987): Morphometry, relative growth and fecundity of the Gulf crab, Callinectes similis, Williams, 1966. Ciencias Marinas, 13, 137-161.

Hartnoll, R. (1985): Growth, sexual maturity and reproduc- 
tive output. pp. 101-128. In: A. M. Wenner (ed.), Factors Influencing Adult Growth. Crustacean Issues, 3, Balkema, Netherlands.

Hernáez, P., Wehrtmann, I. S. (2007): Population biology of the burrowing shrimp Callichirus seilacheri (Decapoda, Thalassinidea, Callianassidae) in northern Chile. Revista de Biología Tropical, 55, 141-152.

Hernáez, P., Palma, S., Wehrtmann, I.S. (2008): Egg production of the burrowing shrimp Callichirus seilacheri (Bott 1955) (Decapoda, Callianassidae) in northern Chile. Helgoland Marine Research, 62, 351-356.

Herrera-Correal, J., Mossolin, E. C., Wehrtmann, I. S., Mantelatto, F. L. (2013): Reproductive aspects of the caridean shrimp Atya scabra (Leach, 1815) (Decapoda: Atyidae) in São Sebastião Island, southwestern Atlantic, Brazil. Latin American Journal of Aquatic Research, 41, 4, 676-684.

Hidalgo, F. J., Firstater, F. N., Lomovasky, B. J., Gallegos, P., Gamero, P., Iribarne, O. O. (2010): Macroalgal fouling on the intertidal mole crab Emerita analoga facilitates bird predation. Helgoland Marine Research, 64, 4, 367-376.

Hines, A. H. (1988): Fecundity and reproductive output in two species of deep-sea crabs Geryon fenneri and $G$. quinquedens (Decapoda: Brachyura). Journal of Crustacean Biology, 8, 4, 557-562.

Hines, A. H. (1991): Fecundity and reproductive output in nine species of Cancer crabs (Crustacea, Brachyura, Candridae). Canadian Journal of Fisheries and Aquatic Sciences, 48, 267-275.

Hubbard, D. M., Dugan, J. E. (2003): Shorebird use of an exposed sandy beach in Southern California. Estuarine, Coastal and Shelf Science, 58S, 41-54.

Lawlor, L.R. (1976a): Molting, growth and reproductive strategies in the terrestrial isopod, Armadillidium vulgare. Ecology, 57, 1179-1194.

Lawlor, L. R. (1976b): Parental investment and offspring fitness in the terrestrial isopod, Armadillidium vulgare (Latr.) (Crustacea: Oniscoidea). Evolution, 30, 775-785.

Lercari, D., Defeo, O. (1999): Effects of freshwater discharge in sandy beach populations: the mole crab Emerita brasiliensis in Uruguay. Estuarine, Coastal and Shelf Science, 49, 457-468.

Love, M.S., Westphal, W. (1981): Growth, reproduction and food habits of olive rockfish, Sebastes serranoides, off central California. U.S. Fishery Bulletin, 79, 533-545.

Mashar, A., Wardiatno, Y. (2013a): Growth aspect of the mole crab, Emerita emeritus of Kebumen District sandy beach. Jurnal Biologi Tropis, 13, 1, 29-38. (in Indonesian)

Mashar, A., Wardiatno, Y. (2013b): Growth aspect of the mole crab, Hippa adactyla of Kebumen District sandy beach. Jurnal Biologi Tropis, 13, 2, 119-127. (in Indonesian)

Mashar, A., Wardiatno, Y., Boer, M., Butet, N.A., Farajallah, A. (2014): The diversity and abundance of sand crabs in south coast of Central Java. IImu Kelautan, 19, 4, 226-
232. (in Indonesian)

Mashar, A., Wardiatno, Y., Boer, M., Butet, N. A., Farajallah, A., Ardika, P. U. (2015): First record of Albunea symmysta (Crustacea: Decapoda: Albuneidae) from Sumatra and Java, Indonesia. AACL Bioflux, 8, 4, 611-615.

Mauchline, J. (1973): The broods of British Mysidacea (Crustacea). Journal of the Marine Biological Association of the United Kingdom, 53, 801-817.

Muzammil, W., Wardiatno, Y., Butet, N. A. (2015): Carapace length-width ratio, relative growth, condition factor, and relative condition factor of the mole crab (Hippa adactyla) in Cilacap and Kebumen sandy beach. Jurnal IImu Pertanian Indonesia, 20, 1, 78-84. (in Indonesian)

Norman, C. P., Jones, M. B. (1993): Reproductive ecology of the velvet swimming crab, Necora puber (Brachyura, Portunidae) at Plymouth. Journal of the Marine Biological Association of the United Kingdom, 73, 379-389.

Paris, O.H., Pitelka, F.A. (1962): Population characteristics of the terrestrial isopod Armadillidium vulgare in California grassland. Ecology, 43, 229-248.

Reynolds, J.D., Celada, J.D., Carral, J.M., Matthews, M.A. (1992): Reproduction of astacid crayfish in captivitycurrent developments and implications for culture, with special reference to Ireland and Spain. Invertebrate Reproduction \& Development, 22, 1-3, 253-266.

Sáez-Royuela, M., Carral, J. M., Celada, J. D., P rez, J. R., Gonzales, A. (2006): Pleopodal egg production of the whiteclawed crayfish Austropotamobius pallipes Lereboullet under laboratory conditions: relationship between egg number, egg diameter and female size. Bulletin Francais De La Peche Et De La Pisciculture, 380-381, 1207-1214.

Santoso J., Hanifa, Y. N., Indariani, S., Wardiatno, Y., Mashar, A. (2015): Nutritional values of the Indonesian mole crab, Emerita emeritus: are they affected by processing methods? AACL Bioflux, 8, 4, 579-587.

Sarong, M. A., Wardiatno, Y. (2013): Habitat and morphological characteristics of gratus nest sea (Albunea) in the coastal zone littoral Leupung, Great Aceh District. Jurnal EduBio Tropika 1, 1, 1-5. (in Indonesian).

Shields, J. D. (1991): The reproductive ecology and fecundity of Cancer crabs. pp. 193-213. In: Wenner, A., Kuris, A. (Eds.), Crustacean egg production. A. A. Balkema, Rotterdam, The Netherlands.

Somers, K. M. (1991): Characterizing size-specific fecundity in crustaceans. pp. 357-378. In: Schram, F. R. (ed.), Crustacean egg production. Crustacean Issues 7. A. A. Balkema, Rotterdam, The Netherlands.

Subramoniam, T. (1977): Continuous breeding in the tropical anomuran crab Emerita asiatica Milne Edwards from Madras coast. pp. 166-174. In: Adiyodi, K.O., Adiyodi, R. O. (eds.), Advanced in Invertebrate Reproduction I. International Society for Invertebrate Reproduction, Karivellue, India.

Subramoniam, T. (1979): Some aspects of reproductive 
ecology of a mole crab Emerita asiatica Mime Edwards. Journal of Experimental Marine Biology and Ecology, 36, 259-268.

Subramoniam, T., Gunamalai, V. (2003): Breeding biology of the intertidal sand crab, Emerita (Decapoda: Anomura). Advances in Marine Biology, 46, 91-182.

Talbot, P. (1991): Ovulation, attachment and retention of lobster eggs. pp. 9-18. In: Wenner, A., Kuris, A. (Eds.), Crustacean egg production. A. A. Balkema, Rotterdam, The Netherlands.

Tamaki, A., Ingole, B., Ikebe, K., Muramatsu, K., Taka, M., Tanaka, M. (1997): Life history of the ghost shrimp, Callianassa japonica Ortmann (Decapoda: Thalassinidea), on an intertidal sandflat in western Kyushu, Japan. Journal of Experimental Marine Biology and Ecology, 210, 223-250.

Taugbøl, T., Skurdal, J. (1990): Effect of density on brood size in noble crayfish in noble crayfish, Astacus astacus L., subjected to indoor rearing conditions. Aquaculture and Fisheries Management, 21, 17-23.

Thessalou, M., Kiortsis, V. (1997): Estimation of the reproductive output of the burrowing shrimp Callianassa tyrrhena: a comparison of three different biometrical approaches. Marine Biology, 127, 435-442.

Turner, R. L., Lawrence, J. M. (1979): Volume and composition of echinoderm eggs: implications for the use of egg size in life history models. pp. 25-40. In: Stancik, S.E. (Ed.), Reproductive ecology of marine invertebrates. The Belle W. Baruch Library Mar. Sci. 9, University of South Carolina Press, Columbia.

Van Dolah, R. F., Bird, E. (1980): A comparison of reproductive patterns in epifaunal and infaunal Gammaridean amphipods. Estuarine and Coastal Marine Science, 11, 593604.

Ver simo, P., Bernárdez, C., González-Gurriarán, E., Freire, J., Muiño, R., Fernández, L. (2011): Changes between consecutive broods in the fecundity of the spider crab,
Maja brachydactyla. ICES Journal of Marine Science, 68, 3, 472-478.

Wardiatno, Y. (2002): Study on the biology of the ghost shrimp, Nihonotrypaea japonica (Ortmann 1891) (Decapoda: Thalassinidea: Callianassidae), distributed on intertidal sandflats in Ariake Sound, Kyushu, Japan. PhD thesis. Nagasaki University, Japan. 185p.

Wardiatno, Y., Nurjaya, I. W., Mashar, A. (2014): Habitat characteristics of the mole crabs (Family Hippidae) in sandy coast, Cilacap District. Jurnal Biologi Tropis, 14, 1, 1-8. (in Indonesian)

Wardiatno, Y., Ardika, P.U., Farajallah, A., Mashar, A., Ismail. (2015a): The mole crab Hippa marmorata (Hombron et Jacquinot, 1846) (Crustacea Anomura Hippidae): a first record from Indonesian waters. Biodiversity Journal, 6, 2, 517-520.

Wardiatno Y., Ardika, P. U., Farajallah, A., Butet, N. A., Mashar, A., Kamal, M. M., Renjaan, E. A., Sarong, M. A. (2015b): Biodiversity of Indonesian sand crabs (Crustacea, Anomura, Hippidae) and assessment of their phylogenetic relationships. AACL Bioflux, 8, 2, 224-235.

Wehrtmann, I. S. (1990): Distribution and reproduction of Ambidexter panamense and Palaemonetes schmitti in Pacific Costa Rica (Crustacea, Decapoda). Revista de Biología Tropical, 38, 327-329.

Wenner, A. M. (1977): Food supply, feeding habits and egg production in Pacific mole crabs (Hippa pacifica Dana). Pacific Science, 31, 39-47.

Wenner, A.M., Hubbard, D.M., Dugan, J., Shoffner, J., Jellison, K. (1987): Egg production by sand crabs (Emerita analoga) as a function of size and year class (Decapoda, Hippidae). The Biological Bulletin, 172, 225-235.

Wickens, J.F., Beard, T.W. (1974): Observations of the breeding and growth of the giant freshwater prawn Macrobrachium rosenbergii (De Man) in the laboratory. Aquaculture, 3, 159-174. 